\title{
PENERAPAN MODEL PEMBELAJARAN INQUIRY TRAINING BERBASIS JUST IN TIME TEACHING (JITT) UNTUK MENINGKATKAN KEMAMPUAN PEMECAHAN MASALAH FISIKA
}

\author{
Teguh Febri Sudarma ${ }^{1}$, Yul Ifda Tanjung ${ }^{2}$ dan Muhammad Kadri ${ }^{2}$ \\ Prodi Fisika Universitas Negeri Medan \\ teguhfebri@gmail.com,
}

\begin{abstract}
Abstrak
Penelitian yang dilaksanakan ini bertujuan untuk mengetahui peningkatan kemampuan pemecahan masalah sebagai hasil belajar dan aktivitas belajar mahasiswa serta pendapat mahasiswa mengenai proses pembelajaran dengan model Inquiry Training berbasis Just In Time Teaching pada mata kuliah Fisika Umum I. Berdasarkan hasil penelitian, analisis data dan pembahasan dapat disimpulkan bahwa: Peningkatan kemampuan pemecahan masalah fisika pada mahasiswa yang mendapatkan model pembelajaran inquiry berbasis JiTT diperoleh persentase rata-rata skor dari 22,67 (38\%) pada tes awal menjadi 30,97 (52\%)Selanjutnya pada sikulus II terjadi peningkatan kemampuan pemecahan masalah dari 42,00 (55\%) pada tes awal menjadi 48,30 (81\%).Peningkatan kemampuan pemecahan masalah dari hasil tes awal diperoleh persentase nilai rata-rata untuk kriteria Polya yang paling tinggi memahami masalah yaitu 70,40 (69\%) dan kriteria paling rendah yaitu memeriksa kembali (MK) 6,57 (44\%). Pada siklus II terjadi peningkatan skor belajar untuk masingmasing kriteria Polya yaitu memahami masalah (MM) dari 10,40 (69\%) menjadi 11,33 (76\%), menyusun perencanaan (MP) dari 8,37 (56\%) menjadi 11,63 (78\%), melaksanakan rencana (MR) dari 7,90 (53\%) menjadi 11,97 (80\%), dan Memeriksa kembali (MK) dari 6,57 (44\%) menjadi 11,33 (76\%). Peningkatan partisipasi mahasiswa pada dari siklus I dengan skor rata-rata aktivitas 42,61 meningkat pada siklus II menjadi 75,03
\end{abstract}

\section{PENDAHULUAN}

Fisika sebagai bagian dari pendidikan sains merupakan hasil pengalaman langsung dari suatu gejala alam, membahas fenomena yang terjadi pada masalah-masalah nyata yang ada di alam, sehingga pembelajaran fisika bukan hanya penguasaan berupa fakta, konsep dan prinsip tetapi juga suatu proses penemuan sistematis yang harus ditempuh siswa dalam menyelesaikan suatu masalah. Pembelajaran fisika diharapkan dapat memberikan pengalaman langsung kepada siswa untuk memahami fisika secara ilmiah.

Fisika umum merupakan bagian dari ilmu fisika yang diajarkan bagi mahasiswa prodi pendidikan fisika dan mata kuliah wajib bersama bagi seluruh mahasiswa FMIPA. Mata kuliah ini merupakan mata kuliah yang mengkaji tentang topik-topik fisika yang menjadi dasar untuk semua mata kuliah fisika lanjut seperti Mekanika, Gelombang, Fisika Modern, Fisika Statistik, Fisika Kuantum, Fisika Inti dan Elektronika Dasar. Mata kuliah ini mendasari pengembangan rekayasa, desain perencanaan, teknologi dan mempunyai peran penting dalam berbagai disiplin serta mampu mengembangkan daya pikir manusia dan proses berpikirnya.

Dalam batasan pembelajaran fisika, mahasiswa dituntut untuk dapat memecahkan masalah fisika berupa soal-soal tes uraian yang berhubungan dengan konsep fisika menggunakan analisis matematika sebagai bentuk hasil belajar. Namun kenyataannya dari hasil studi pendahuluan pada mata kuliah Fisika Umum, mahasiswa sering mengalami kesulitan mengerjakan soal-soal tersebut. Dari hasil uji coba soal-soal uraian fisika menggunakan teknik Polya terhadap 45 orang mahasiswa Angkatan 2013 Jurusan Fisika FMIPA Unimed T.A.2013/2014 yang telah memperoleh mata kuliah Fisika Umum I dan II (2014) diperoleh hanya sekitar $23 \%$ sampai pada tahapan melaksanakan rencana dan $77 \%$ lagi sampai pada tahapan menyusun rencana. Hal ini menjelaskan bahwa hampir lebih dari $70 \%$ mahasiswa tidak mampu menyelesaikan soal-soal fisika berbentuk masalah. Padahal soal-soal tersebut termasuk kategori mudah dan sering dijadikan contoh soal dalam diktat fisika.

Sejalan dengan hasil ujicoba, simpulan pendapat 45 orang mahasiswa angkatan 2013 Jurusan Fisika FMIPA Unimed T.A.2013/2014 (2014) bahwa 73,5\% menyatakan bahwa konsepkonsep materi pada Fisika Umum sulit dipahami dan sebagian besar mahasiswa belum mampu memecahkan masalah yang berhubungan dengan konsep fisika karena mahasiswa selalu dituntut untuk menghapal rumus-rumus tanpa berusaha memaknai arti dan fungsi rumus. Mahasiswa menggunakan pendekatan plug and chug dan memory-based dalam memecahkan soal-soal fisika (Walsh, 2007; Brad, 2011; Erceg, 2011). Pengaruhnya kemampuan mahasiswa dalam membentuk hubungan sebab akibat sampai kepada kemampuan membangun konsep baru akan sulit dimunculkan. Sehingga secara tidak langsung mahasiswa menganggap materi fisika itu sulit (Ornek, dkk., 2008; Wijayanti, dkk., 2010).

Kenyataan di lapangan, dosen pengampu mata kuliah Fisika Umum telah berupaya 
melaksanakan proses pembelajaran dengan model yang bervariasi. Berdasarkan hasil studi pendahuluan dan wawancara dengan sampel 15 orang dosen pengampu mata kuliah Fisika Umum Jurusan Fisika FMIPA Unimed T.A.2013/2014 (2013), hampir $80 \%$ dosen melaksanakan pembelajaran Fisika Umum sesuai dengan sintaks model pembelajaran koperatif. Dengan model pembelajaran koperatif mahasiswa sudah aktif terlibat dalam kegiatan pembelajaran seperti bekerja dalam masyarakat belajar, presentase dan mengajukan pertanyaan ataupun memberikan ide dalam menyelesaikan permasalahan fisika. Idealnya dengan model pembelajaran koperatif hasil belajar Fisika Umum sudah memuaskan, tapi kenyataan dari nilai mata kuliah Fisika Umum I dari 3 kelas yang diajarkan dengan model pembelajaran Kooperatif diperoleh hanya $17,8 \%$ nilai A, $38,13 \%$ nilai B, $39,4 \%$ nilai C dan $4,6 \%$ nilai E. Distribusi nilai seperti di atas diperoleh karena acuan penilaian yang digunakan belum sepenuhnya menggunakan penilaian acuan patokan (PAP) tetapi masih menggunakan gabungan acuan patokan dan acuan normal. Jika digunakan penilaian acuan patokan dalam penentuan nilai akhir sebagaimana yang dilakukan pada penilaian tes standar Tahun Ajaran 2014/2015 hanya sekitar 45\% mahasiswa yang memperoleh nilai $\mathrm{C}$ selebihnya memperoleh nilai E. Rendahnya nilai hasil belajar Fisika Umum berdasarkan pemahaman konsepnya sejalan dengan temuan penelitian sebelumnya (Saleh 2011:6990; Gaigher, et al., 2007:1110; dan Baser, 2006:79).

Fakta berdasarkan hasil studi pendahuluan menunjukkan masih perlu diadakan perbaikan pada kegiatan perkuliahan Fisika Umum. Perolehan nilai yang masih rendah karena mahasiswa belum sepenuhnya memahami konsep fisika secara menyeluruh sehingga mahasiswa sulit menyelesaikan soal-soal berbentuk masalah. Oleh karena itu, dosen dituntut mencari dan menemukan suatu cara yang dapat membantu mahasiswa memahami konsep fisika sehingga secara tidak langsung dapat melatih kemampuan pemecahan masalah fisika mahasiswa melalui kegiatan pembelajaran. Hal ini sesuai dengan salah satu tujuan dari pendidikan tinggi, yaitu mentransformasikan dan mengembangkan kemampuan mahasiswa, termasuk untuk merancang apa yang dilakukan, melaksanakan apa yang sudah direncanakan, memonitor dan mengevaluasi apa yang sedang dan sudah dilakukan, sehingga mereka menjadi kritis, kreatif, inovatif, mandiri, percaya diri dan bertanggung jawab (Peraturan Pemerintah nomor 17 tahun 2010 tentang pengelolaan dan penyelenggaraan pendidikan).

Salah satu upaya yang dapat dilakukan dosen adalah merancang kegiatan pembelajaran berbasis pada pemecahan masalah dan melakukan penyelidikan. Pengertian yang lebih luas mengandung makna bahwa dosen diharapkan dapat menerapkan suatu model pembelajaran yang dapat meningkatkan kemampuan menemukan, mengembangkan, menyelidiki dan mengungkapkan ide mahasiswa sendiri. Model pembelajaran yang dimaksud adalah model dengan pendekatan inkuiri yang dikembangkan oleh Suchman yaitu model pembelajaran Inquiry Training.

Model Inquiry Training dipilih, karena memiliki karakteristik yang sesuai dengan mahasiswa Jurusan Fisika yaitu: 1) dapat memecahkan masalah sesuai tahapan yang terpilih, dengan menggunakan curah pendapat dan teknis investigasi masalah, 2) membangun ilmu yang telah dimiliki dan 3) mengoperasikan alat-alat laboratorium yang berkaitan dengan teori yang diberikan 4) mempergunakan media yang ada, dan dapat melakukan teknik analisis, 5) menganalisis dan mendeskripsikan, mendiskusikan hasil data praktikum dengan cara laporan tertulis, poster, dan presentasi lisan, 6) bekerja dalam kelompok dengan mengorganisasi tiap-tiap kelompok (Bound\&Ton, 2005:38). Hal ini menjelaskan bahwa model pembelajaran Inquiry Training sangat efektif dilakukan karena dikombinasi dengan strategi Just In Time Teaching (JITT) menggunakan media internet yang dapat mengajak mahasiswa langsung kepada pemecahan masalah sehingga secara tidak langsung dapat meningkatkan kemampuan pemecahan masalah.

\section{METODE PENELITIAN}

Penelitian ini dilaksanakan di Jurusan Fisika FMIPA Unimed pada mahasiswa semester ganjil yang mendapat mata kuliah Fisika Umum I. Interval waktu penelitian akan dimulai dengan survei pendahuluan, penyusunan proposal penelitian, uji coba instrumen, pengumpulan data, analisis data, dan akhirnya penulisan laporan penelitian dan publikasi

artikel ilmiah. Metode penelitian yang digunakan dalam penelitian ini adalah penelitian tindakan berbasis kelas yang diadopsi dari desain model PTK Mc. Taggert dalam Hopkins (2011:92) 


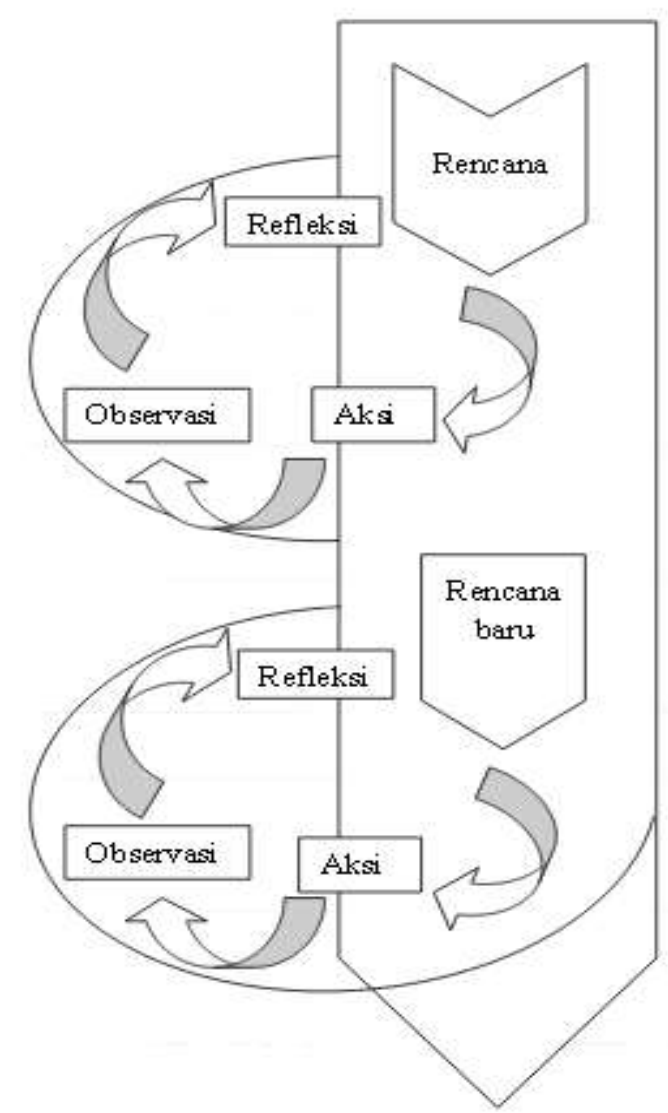

Gambar 3.1. "Spiral Penelitian Tindakan” Model Kemmis dan Mc. Taggart

Secara singkat penelitian tindakan kelas didefinisikan sebagai bentuk kajian yang bersifat reflektif oleh pelaku tindakan, yang dilakukan untuk meninggikan kemantapan rasional dari tindakan-tindakan mahasiswa dalam melaksanakan tugas, memperdalam pemahaman terhadap tindakan-tindakan yang dilakukannya itu, serta memperbaiki kondisi dimana praktek-praktek pembelajaran tersebut dilakukan.

Setelah dilakukan perenungan atau refleksi yang mencakup analisis, sintesis, dan penilaian terhadap hasil pengamatan proses serta hasil tindakan tadi, kemungkinan muncul permasalahan atau pemikiran baru yang perlu mendapat perhatian, sehingga pada gilirannya perlu dilakukan perencanaan ulang.

\subsection{Prosedur Penelitian}

Langkah-langkah

direncanakan sebagai berikut :

\section{Tahap persiapan}

Pada tahap persiapan dilakukan beberapa kegiatan, yaitu mengembangkan perangkat pembelajaran (bahan ajar dan lembar kerja untuk diterapkan menggunakan media website), menyusun instrumen dan menvalidasi isinya, mengujicobakan lembar kerja kepada beberapa mahasiswa diluar sampel, mengujicobakan soalsoal tes kemampuan pemecahan masalah, melakukan observasi terhadap aktivitas mahasiswa dalam melakukan eksperimen, merevisi perangkat pembelajaran dan terakhir memilih sampel secara acak terhadap seluruh mahasiswa Jurusan Fisika.

Dalam penelitian ini, kemampuan pemecahan masalah yang dimaksud adalah kemampuan mahasiswa menggunakan pengetahuan-pengetahuan dan konsep-konsep pada materi Fisika Umum I yang dipahaminya untuk memecahkan masalah yang berhubungan dengan permasalahan bersifat translasi. Kemampuan pemecahan masalah mahasiswa akan diukur dengan instrumen tes dalam bentuk uraian dengan pedoman penskoran pemecahan masalah yang dibuat oleh Selcuk (2008:153) yaitu Problem Solving Performance Test (PSPT) berdasarkan empat kriteria rubrik penilaian mengikuti teknik pemecahan masalah Polya. Rubrik kriteria dirancang untuk mengukur kualitas dari pemecahan masalah.

\section{Tahap Pelaksanaan}

Tahap pelaksanaan diawali dengan mengadakan studi eksplorasi untuk memahami kondisi kelas dan mahasiswa. Hal ini dimaksudkan untuk menggali informasi tentang keadaan mahasiswa secara akademik. Selanjutnya melaksanakan pembelajaran untuk suatu topik tertentu berdasarkan model pembelajaran yang telah dirancang, mengadakan refleksi berdasarkan pada hasil studi eksplorasi dan diikuti dengan perencanaan tindakan siklus kedua, sekaligus memperbaiki kelemahan dalam pembelajaran, melakukan tindakan atau perlakuan pada mahasiswa dalam kelas, dan pada saat yang sama melakukan observasi kelas dan refleksi, dan seterusnya sampai siklus ketiga, sehingga diharapkan pada akhir penelitian ini diperoleh hasil peningkatan kemampuan pemecahan masalah dan aktivitas mahasiswa.

\section{Tahap Analisis Data}

Sebelum implementasi model pembelajaran dilakukan tes awal (pretes) dan setelah implementasi model pembelajaran dilakukan tes akhir (postes). Hasil pretes dan postes diolah dan dianalisis untuk mengetahui peningkatan kemampuan pemecahan masalah mahasiswa. Untuk mengetahui peningkatan hasil belajar antara sebelum dan sesudah pembelajaran dari setiap siklus diklasifikasikan berdasarkan nilai persentase gain ternormalisasi yang dihitung dengan rumus dari Hake (dalam Savinainen \& Scott, 2002) : 


$$
\% g=\frac{\left(S_{\text {pos }}\right)-\left(S_{\text {pre }}\right)}{\left(S_{\text {max }}-S_{\text {pre }}\right)} \times 100
$$

Dimana $\left(S_{\text {pos }}\right)$ dan $\left(S_{\text {pre }}\right)$ masing-masing menyatakan skor tes akhir dan skor tes awal, sedangkan $\left(\mathrm{S}_{\max }\right)$ menyatakan skor maksimum ideal setiap individu. Nilai $\% g$ kemudian dikonversikan kriteria gain ternormalisasi yaitu tingkat gain 71 - 100 kriterianya tinggi, 31 - 70 kriterianya sedang dan $0-30$ rendah.

\subsection{Indikator Keberhasilan}

Tolak Ukur keberhasilan Penelitian Tindakan Kelas ini adalah :

1. Peserta didik dipandang mencapai tuntas belajar psikomotorik, afektip apabila seluruhnya atau setidak-tidaknya $75 \%$ peserta didik terlibat aktif, baik fisik, mental maupun sosial dalam proses pembelajaran (Mulyasa, 2003:101). Dalam penelitian ini tuntas belajar psikomotorik yang dimaksud adalah aktivitas mahasiswa dalam pembelajaran

2. Peserta didik mencapai tuntas belajar kognitif apabila mampu menyelesaikan, menguasai kompetensi atau tujuan pembelajaran minimal $65 \%$ dari seluruh tujuan pembelajaran. Sedangkan keberhasilan kelas diperoleh dari jumlah peserta didik yang mampu menyelesaikan atau mencapai minimal $65 \%$, sekurangkurangnya $85 \%$ dari jumlah keseluruhan yang mengikuti tes (Mulyasa,2003:99). Dalam penelitian ini tuntas belajar kognitif yang dimaksud adalah ketuntasan kemampuan pemecahan masalah fisika mahasiswa. Ketuntasan individu digunakan untuk menentukan ketuntasan secara klasikan, sedangkan ketuntasan klasikan digunakan untuk menetukan keberlangsungan penelitian tindakan kelas (siklus selanjutnya)

Keberlanjutan dari pembelajaran ini dapat terlaksana mengingat komitmen dosen dan pimpinan sudah tinggi. Dengan adanya learning revolution yang berfokus kepada pembelajaran berpusat pada mahasiswa (student center learning) dan penggunaan sarana/media pembelajaran berbasis IPTEK seperti media internet membuat dosen semakin komit terhadap pelaksanaan model pembelajaran ini.

\section{HASIL PENELITIAN DAN PEMBAHASAN}

\subsection{Hasil Penelitian \\ 4.1.1. Hasil test}

Tes yang diberikan merupakan tes kemampuan pemecahan masalah mahasiswa dalam bentuk tes uraian. Tes dilakukan sebelum dan sesudah mengikuti pembelajaran. Hasil tes awal digunakan untuk melihat kemampuan awal mahasiswa sedangkan hasil tes akhir digunakan untuk membandingkan kemampuan pemecahan masalah mahasiswa setelah menerima pembelajaran. Selanjutnya hasil tes awal dan tes akhir digunakan untuk menghitung peningkatan kemampuan pemecahan masalah mahasiswa pada materi fisika umum I yang dinyatakan dalam persentase. Kemampuan awal mahasiswa sebelum dilakukan pembelajaran dan kemampuan akhir setelah dilakukan pembelajaran terangkum dalam tabel 4.1.

Tabel 4.1. Data Kemampuan Awal dan Akhir Mahasiswa

\begin{tabular}{|c|c|c|c|c|c|}
\hline \multirow{2}{*}{\multicolumn{2}{|c|}{ Tes }} & \multicolumn{4}{|c|}{ Siklus I } \\
\hline & & \multirow{2}{*}{$\frac{\mathrm{N}}{30}$} & \multirow{2}{*}{$\begin{array}{l}X \text { min } \\
16\end{array}$} & \multirow{2}{*}{$\begin{array}{c}\mathrm{X} \\
\max \\
35 \\
\end{array}$} & \multirow{2}{*}{$\frac{X}{22,67}$} \\
\hline Tes & Skor & & & & \\
\hline Awal & $\%$ & 100 & $32 \%$ & $58 \%$ & $38 \%$ \\
\hline \multirow{2}{*}{$\begin{array}{l}\text { Tes } \\
\text { Akhir }\end{array}$} & Skor & 30 & 26 & 40 & 30,97 \\
\hline & $\%$ & 100 & $43 \%$ & $67 \%$ & $52 \%$ \\
\hline \multirow{2}{*}{$\begin{array}{l}\mathrm{N}- \\
\text { gain }\end{array}$} & Skor & 30 & 0,23 & 0,2 & 0,22 \\
\hline & $\%$ & 100 & $23 \%$ & $20 \%$ & $22 \%$ \\
\hline \multirow{2}{*}{\multicolumn{2}{|c|}{ Tes }} & \multicolumn{4}{|c|}{ Siklus II } \\
\hline & & $\mathrm{N}$ & $X \min$ & $\begin{array}{c}X \\
\max \end{array}$ & $X$ \\
\hline \multirow{2}{*}{$\begin{array}{l}\text { Tes } \\
\text { Awal }\end{array}$} & Skor & 30 & 28 & 41 & 33,23 \\
\hline & $\%$ & $100 \%$ & $47 \%$ & $68 \%$ & $55 \%$ \\
\hline \multirow{2}{*}{$\begin{array}{l}\text { Tes } \\
\text { Akhir }\end{array}$} & Skor & 30 & 42 & 55 & 48,3 \\
\hline & $\%$ & $100 \%$ & $70 \%$ & $92 \%$ & $81 \%$ \\
\hline \multirow{2}{*}{$\begin{array}{l}\mathrm{N}- \\
\text { gain }\end{array}$} & Skor & 30 & 0,44 & 0,74 & 0,56 \\
\hline & $\%$ & $100 \%$ & $44 \%$ & $74 \%$ & $56 \%$ \\
\hline
\end{tabular}

Dari tabel 4.1 terlihat bahwa pada saat siklus I skor rata-rata tes awal adalah 22,67 (38\%) dan skor rata-rata tes akhir30,97 (52\%) dari skor ideal 60. Selanjutnya kegiatan pada siklus II diperoleh hasil skor rata-rata tes awal 42,00 (55\%) dan pada tes akhir diperoleh rata-rata sebesar 48,30 $(81 \%)$. Rata-rata N-gain pada saat siklus I diperoleh sebesar 0,22 (22\%) yang dapat dikategorikan rendah dan pada siklus II skor ratarata $\mathrm{N}$-gain adalah sebesar $0,56(56 \%)$ yang dapat dikategorikan sedang. Perubahan nilai tes awal dengan nilai tes akhir untuk masing-masing siklus dan perubahan $\mathrm{N}$-gain untuk setiap siklus dapat dilihat pada gambar 4.1. 


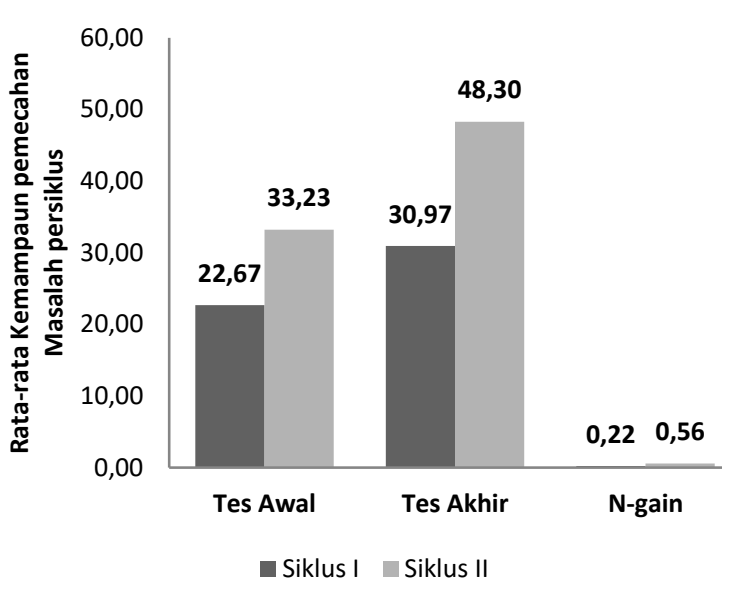

Gambar 4.1. Grafik Perubahan Nilai Tes Awal, Tes Akhir dan N-gain

\subsubsection{Deskripsi Kemampuan Pemecahan Masalah}

Berdasarkan instrumen tes kemampuan pemecahan masalah (teknik Polya) yang dikembangkan peneliti dimana terdiri dari beberapa klasifikasi soal tes antara lain Memahami Masalah (MM), Menyusun Perencanaan (MP), Melaksanakan Rencana (MR), dan Memeriksa Kembali (MK). Adapun deskripsi kemampuan pemecahan masalah pada setiap siklus dengan memperhatikan klasifikasi soal ditunjukan pada tabel 4.2.

Tabel 4.2. Rata-Rata Hasil Tes Berdasarkan Kriteria Polya

\begin{tabular}{|c|c|c|c|c|c|c|}
\hline \multirow{3}{*}{$\begin{array}{c}\text { Kriteria } \\
\text { Polya }\end{array}$} & \multicolumn{6}{|c|}{ Rata-rata Hasil Tes } \\
\cline { 2 - 7 } & \multicolumn{3}{|c|}{ Siklus I } & \multicolumn{3}{c|}{ Siklus II } \\
\cline { 2 - 7 } & $\begin{array}{c}\text { Tes } \\
\text { Awal }\end{array}$ & $\begin{array}{c}\text { Tes } \\
\text { Akhir }\end{array}$ & $\begin{array}{c}\text { N- } \\
\text { gain }\end{array}$ & $\begin{array}{c}\text { Tes } \\
\text { Awal }\end{array}$ & $\begin{array}{c}\text { Tes } \\
\text { Akhir }\end{array}$ & $\begin{array}{c}\text { N- } \\
\text { gain }\end{array}$ \\
\hline MM & 8,80 & 9,23 & 0,07 & 10,40 & 11,33 & 0,20 \\
\hline MP & 6,50 & 7,70 & 0,14 & 8,37 & 11,63 & 0,49 \\
\hline MR & 7,07 & 7,70 & 0,08 & 7,90 & 11,97 & 0,57 \\
\hline MK & 0,30 & 0,76 & 0,03 & 6,57 & 11,33 & 0,57 \\
\hline
\end{tabular}

Dari hasil pelaksanaan tes awal dan tes akhir untuk masing-masing kriteria Polya yang ditunjukan pada tabel 4.2 dapat dilihat bahwa nilai terendah pada tes awal untuk siklus I terjadi pada memeriksa kembali (MK) yaitu 0,30 (2\%) dan nilai paling tinggi ada pada kriteria memahami masalah (MM) yaitu $8,80 \quad(59 \%)$. Setelah dilakukan pembelajaran dengan model inquiry berbasis JiTT terjadi peningkatan pada masing-masing kriteria Polya yaitu untuk memeriksa kembali (MM) dari $8,80 \quad(59 \%)$ menjadi $9,23(62 \%)$, menyusun perencanaan (MP) dari 6,50 (43\%) menjadi 7,70 (51\%), melaksanakan rencana (MR) dari 7,07 (47\%) menjadi 7,70 (51\%) dan memeriksa kembali (MK) dari 0,30 (2\%) menjadi 0,76 (5\%).
Setelah proses pembelajaran pada siklus I selesai, maka pada siklus kedua kembali dilakukan tes awal sebelum mulai pembelajaran. Dari hasil tes awal diperoleh persentase nilai rata-rata untuk kriteria Polya yang paling tinggi memahami masalah yaitu 70,40 (69\%) dan kriteria paling rendah yaitu memeriksa kembali (MK) 6,57 (44\%). Pada siklus II terjadi peningkatan skor belajar untuk masing-masing kriteria Polya yaitu memahami masalah (MM) dari 10,40 (69\%) menjadi $11,33(76 \%)$, menyusun perencanaan (MP) dari 8,37 (56\%) menjadi 11,63 (78\%), melaksanakan rencana (MR) dari 7,90 (53\%) menjadi 11,97 (80\%), dan Memeriksa kembali (MK) dari 6,57 (44\%) menjadi 11,33 (76\%).

Untuk perolehan rata-rata $\mathrm{N}$-gain terlihat bahwa pada masing-masing kriteria Polya pada siklus satu masih tergolong rendah yakni memahami masalah (MM) 0,07, menyusun perencanaan (MP) 0,14, melaksanakan rencana (MR) 0,08 dan memeriksa kembali (MK) 0,03. Pada siklus II diperoleh rata-rata $\mathrm{N}$-gain meningkat dari perolehan pada siklus I untuk masing-masing kriteria Polya yakni memahami masalah (MM) 0,20, menyusun perencanaan (MP) 0,49, melaksanakan rencana (MR) 0,57, dan memeriksa kembali (MK) 0,57.

\subsubsection{Hasil Pengamatan Partisipasi Mahasiswa}

Berdasarkan tabel realisasi pengamatan aktivitas mahasiswa pada proses pembelajaran yang ditunjukan pada tabel 4.3 bahwa pengamatan terhadap kemampuan afektif dan psikomotorik mahasiswa dilakukan pada pertemuan pertama dan kedua.

Tabel 4.3 Aktivitas Belajar Mahasiswa

\begin{tabular}{|c|c|c|c|}
\hline \multirow[t]{2}{*}{ No } & \multirow[t]{2}{*}{ Aktivitas } & \multicolumn{2}{|c|}{$\begin{array}{c}\text { Persentase } \\
\text { Aktivitas Selama } \\
\text { Pembelajaran (\%) }\end{array}$} \\
\hline & & $\begin{array}{c}\text { Siklus } \\
\text { II }\end{array}$ & $\begin{array}{c}\text { Siklus } \\
\text { III }\end{array}$ \\
\hline 1 & $\begin{array}{l}\text { Partisipasi } \\
\text { mahasiswa dalam } \\
\text { diskusi kelompok }\end{array}$ & 35,2 & 75,7 \\
\hline 2 & $\begin{array}{l}\text { Partisipasi } \\
\text { mahasiswa dalam } \\
\text { diskusi kelas }\end{array}$ & 40,5 & 70,3 \\
\hline 3 & $\begin{array}{l}\text { Banyaknya } \\
\text { mahasiswa yang } \\
\text { bertanya dalam } \\
\text { diskusi kelas }\end{array}$ & 51,4 & 78,4 \\
\hline 4 & $\begin{array}{l}\text { Banyaknya } \\
\text { mahasiswa yang } \\
\text { menanggapi } \\
\text { pertanyaan dalam } \\
\text { diskusi kelas }\end{array}$ & 27 & 56,8 \\
\hline
\end{tabular}




\begin{tabular}{|c|l|c|c|}
\hline 5 & $\begin{array}{l}\text { Ketepatan waktu } \\
\text { dalam } \\
\text { menyelesaikan } \\
\text { tugas }\end{array}$ & 64,9 & 86,5 \\
\hline 6 & $\begin{array}{l}\text { Partisipasi } \\
\text { kelompok dalam } \\
\text { diskusi kelas }\end{array}$ & $\begin{array}{l}\text { Kemampuan } \\
\text { menyelesaikan } \\
\text { tugas dengan baik } \\
\text { dan benar }\end{array}$ & 56,7 \\
\hline 8 & $\begin{array}{l}\text { Kemampuan } \\
\text { berkomunikasi } \\
\text { (presentasi) }\end{array}$ & 16,2 & 78,4 \\
\hline
\end{tabular}

Berdasarkan tabel 4.3 dapat dilihat bahwa terjadi peningkatan partisipasi mahasiswa dari siklus I ke siklus II untuk masing-masing aktivitas.

\subsection{Pembahasan}

\subsubsection{Tindakan}

Berdasarkan data pada kondiri awal menunjukan bahwa kemampuan awal mahasiswa sangat rendah. Hal ini dapat dilihat dari tes awal sebelum pembelajaran persentase skor rata-rata $58 \%$ dari skor idealnya 60 . Dari hasil pengamatan dapat disimpulkan bahwa mahasiswa belum menguasai materi pembelajaran setidaknya $65 \%$ dari seluruh materi yang akan direncanakan pada proses perkuliahan.

Setelah dilakukan pembelajaran diperoleh persentase rata-rata skor dari tes kemampuan pemecahan masalah mahasiswa sebesar 40,00 (67\%) dari skor ideal 60. Dari analisis kriteria teknik Polya memeriksa kembali (MK) merupakan kriteria yang paling rendah nilainya dari empat kriteria Polya. Hasil analisis untuk masing-masing kriteria Polya ditunjukan oleh grafik pada gambar 4.2. Pada grafik tersebut ditunjukan bahwa kriteria teknik Polya memahami masalah (MM) merupakan yang paling tinggi skornya.

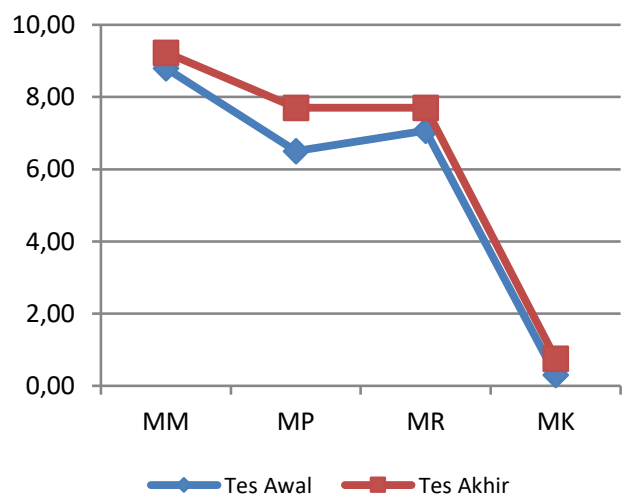

Gambar 4.2. Skor Kriteria Polya pada Siklus I

Setelah ditelusuri penyebab belum maksimalnya kemampuan pemecahan masalah mahasiswa dari setiap indikator melalui analisis catatan-catatan hasil pengamatan oleh 1 orang pengamat, ternyata sebagian besar mahasiswa belum mampu dengan cepat menganalisis masalah-masalah yang disajikan dalam bentuk soal uraian, kemampuan memahami masalah mahasiswa hanya sebatas pada kemampuan memahami soal buka memahami intisari masalah sehingga mahasiswa sulit melaksanakan butir perencanaan, melaksanakan rencana sampai memeriksa kembali hasil pelaksanaan rencana. Masalah ini disebabkan kurangnya minat siswa dalam bertanya dan mengumpulkan bahan dari berbagai sumber belajar sehingga menimbulkan kesulitan siswa untuk membahas soal yang diberikan. Dalam penyelesaian soal-soal tersebut siswa mengalami waktu yang kurang sehingga analisis soal tidak sesuai dengan yang diharapkan sehingga indikator kemampuan pemecahan masalah dari setiap butir soal tidak diperoleh mahasiswa secara maksimal.

Masalah lain adalah pada saat penyajian hasil analisis soal yang tergesa-gesa karena keterbatasan waktu sehingga siswa kurang mengaktifkan kegiatan tanya jawab, padahal kegiatan tanya jawab tersebut amat penting sebagai sarana siswa untuk menghubungkan pemahamannya dengan konsep teori yang ada. Selain itu, mahasiswa belum sepenuhnya paham dan belum terbiasa menggunakan kelas JiTT padahal contoh soal dan uraian penyelesaian telah lengkap disajikan pada web JiTT yang disiapkan oleh peneliti. Belum optimalnya hasil belajar pada siklus I, serta kekurangan-kekurangan tersebut menjadi perhatian khusus bagi peneliti sebagai bahan refleksi untuk menetapkan tindakan pada siklus II.

b.Refleksi dan Perbaikan Tindakan Pada Siklus I

Untuk mengatasi kelemahan-kelemahan yang timbul pada saat pembelajaran siklus I, siswa diberi perbaikan tindakan dan refleksi pada siklus II. Urutan pembelajaran dan waktu yang digunakan sama dengan tindakan pada siklus I, yang berbeda hanya pada penekanan penilaian tugas yang dikerjakan mahasiswa pada kelas JiTT. Hal inidilakukan agar mahasiswa dapat lebih memahami penggunaan kelas web untuk mendukung pemahaman materi Fisika Umum I yang akan diajarkan pada kelas Inquiry. Pada kelas Inquiry, dosen aktif melihat penempatan kelompok mahasiswa yaitu mahasiswa yang memiliki kemampuan lebih baik diposisikan menyebar pada masing-masing kelompok agar menjadi pendukung keaktifan mahasiswa selama melaksanakan kegiatan diskusi. Selain itu mahasiswa diberi tambahan waktu untuk melatih kemampuannya menganalisis masalah-masalah 
yang berkaitan dengan materi Fisika Umum I sehingga mahasiswa dapat menyelesaikan soalsoal berbantuk masalah dengan tepat dan akurat.

Kegiatan pembelajaran pada siklus II secara umum diawali dengan kelas JiTT yaitu mahasiswa mempelajari materi yang ada di website JiTT dan menyelesaikan soal-soal masalah agar pada kelas Inquiry mahasiswa lebih paham dengan materi Fisika Umum I dan dapat menghemat waktu penyelesaian soal-soal yang disajikan. Pada kelas JiTT, pembelajaran yang dilakukan sifatnya pengenalan mahasiswa sehingga waktu pembelajaran pada kelas Inquiry dapat digunakan lebih efektif untuk mencapai tujuan pembelajaran. Masalah alokasi waktu yang kurang dapat diselesaikan apabila mahasiswa mampu mengaktifkan kelas JiTT secara maksimal. Selanjuntya pada kelas Inquiry, selama dosen menjelaskan mahasiswa harus menyiapkan suatu bentuk kasus yang berkaitan dengan materi untuk bahan diskusi dan pertanyaan ke dosen, selanjutnya mahasiswa diberikan contoh-contoh soal kasus yang akan dianalisis melalui diskusi kelompok dengan bantuan sumber belajar buku teks dan handout. Pada saat kegiatan diskusi kelompok dosen terus berupaya mengoptimalkan kegiatan tanya jawab sebagai bahan acuan dosen untuk mengetahui seberapa jauh pemahaman mahasiswa terhadap bahan diskusi yang diberikan. Kegiatan mahasiswa dilaksanakan dengan waktu yang lebih banyak dibandingkan kegiatan yang dilakukan dosen, hal ini bertujuan agar mahasiswa memiliki lebih banyak kesempatan untuk mempelajari cara menganalisis masalah-masalah yang berhubungan dengan materi dan mampu menyelesaikan soal-soal berbentuk masalah. Dalam hal penggunaan kelas JiTT, mahasiswa dituntut untuk menyelesaikan soal yang ada sehingga kemampuan pemecahan masalah mahasiswa juga dapat lebih meningkat dibandingkan pada siklus I.

\subsubsection{Temuan Penelitian Pada Siklus II}

Untuk N-gain masing-masing kriteria Polya dapat dilihat pada gambar 4.3. Dari grafik tersebut dapat dilihat bahwa terjadi peningkatan masing-masing kriteria Polya. Kriteria Polya yang paling tinggi mengalami peningkatan adalah pada indikator Membuat Perencanaan (MP). Hal ini menandakan pada siklus II mahasiswa telah mampu menganalisis soal dan menentukan solusi pemecahannya dalam butir Membuat Perencanaan (MP). Pada butir Melaksanakan Rencana (MR), mahasiswa mengaplikasikan rencana solusi sehingga diperoleh hasil yang akurat. Berikut adalah gambar perolehan rata-rata $\mathrm{N}$-gain setiap siklus.

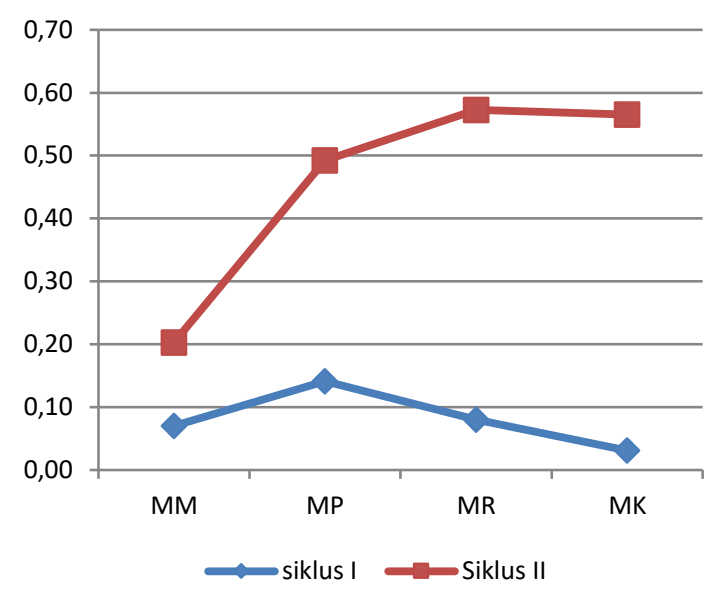

Gambar 4.3 rata-rata N-gain setiap siklus

Dari hasil pengamatan yang dilakukan oleh penelitian dapat dijelaskan bahwa untuk masing-masing indikator Polya pada siklus II sudah mengalami peningkatan dan dikategorikan baik. Hal ini dilihat dari rata-rata skor pada setiap kriteria penilaian Polya yaitu sebesar 11,33 (76\%) memahami masalah (MM), 11,63 (78\%) menyusun perencanaan (MP), $11,97 \quad(80 \%)$ menjalankan rencana (MR), dan 11,33 (76\%) memeriksa kembali (MK). Hasil ini lebih besar daripada perolehan persentase kriteria Polya pada sklus I. Hal ini menggambarkan kualitas pembelajaran semakin baik (terjadi peningkatan) yang pada dasarnya tidak terlepas dari upayaupaya menyempurnakan setiap tindakan yang dilakukan, serta keterampilan dalam mempersiapkan dan melaksanakan model pembelajaran Inquiry Training berbasis JiTT dengan mengoptimalkan upaya peningkatan kemampuan pemecahan masalah mahasiswa. Demikian juga terjadinya peningkatan pengetahuan dan aktivitas berlajarnya baik dalam kegiatan pembelajaran untuk menganalisis masalah-masalah yang berkaitan dengan materi maupun di luar kegiatan pembelajaran yang pada dasarnya berguna untuk memantapkan materi pembelajaran yang telah diperolehnya.

\subsubsection{Refleksi}

Ada beberapa hal yang perlu diperhatikan dari hasil tes dan aktivitas mahasiswa, diantaranya hasil tes awal dan tes akhir pada siklus I dan juga kemampuan mahasiswa dalam menyelesaikan masalah. Sehingga perlu dilakukan refleksi untuk menampung kesulitan yang dihadapi oleh setiap mahasiswa maupun yang dihadapi setiap kelompok. Dalam kegiatan refleksi ini juga dijelaskan kepada mahasiswa kemampuan pemecahan masalah mahasiswa sehingga setiap mahasiswa mengetahui kelemahan diri dalam mengikuti pembelajaran. Dalam refleksi ini beberapa mahasiswa menyatakan bahwa dosen 
perlu mengalokasikan waktu untuk menjelaskan Kriteria teknik Polya.

Kegiatan pembelajaran yang terjadi terdiri dari 2 siklus. Berdasarkan temuan peneliti dan rata-rata skor indikator Polya pretes dan postes dari setiap siklus yang disajikan pada gambar 4.3. Peningkatan yang terjadi relatif baik dan masingmasing indikator Polya dapat dibangun oleh mahasiswa. Berdasarkan hal teresbut, penerapan model Inquiry Training berbasis JiTT dapat meningkatkan kemampuan pemecahan masalah mahasiswa. Peningkatan kemampuan pemecahan masalah yang dimaksud meliputi indikator : memahami masalah (MM), menyusun perencanaan (MP), menjalankan rencana (MR), dan memeriksa kembali (MK)

\section{Simpulan}

Berdasarkan hasil penelitian, analisis data dan pembahasan dapat disimpulkan bahwa:

1. Peningkatan kemampuan pemecahan masalah fisika pada mahasiswa yang mendapatkan model pembelajaran inquiry berbasis JiTT diperoleh persentase rata-rata skor dari 22,67 (38\%) pada tes awal menjadi 30,97 (52\%)Selanjutnya pada sikulus II terjadi peningkatan kemampuan pemecahan masalah dari $42,00(55 \%)$ pada tes awal menjadi 48,30 (81\%).

2. Peningkatan kemampuan pemecahan masalah dari hasil tes awal diperoleh persentase nilai rata-rata untuk kriteria Polya yang paling tinggi memahami masalah yaitu 70,40 (69\%) dan kriteria paling rendah yaitu memeriksa kembali (MK) 6,57 (44\%). Pada siklus II terjadi peningkatan skor belajar untuk masing-masing kriteria Polya yaitu memahami masalah (MM) dari 10,40 (69\%) menjadi 11,33 (76\%), menyusun perencanaan (MP) dari 8,37 (56\%) menjadi 11,63 (78\%), melaksanakan rencana (MR) dari 7,90 $(53 \%)$ menjadi 11,97 (80\%), dan Memeriksa kembali (MK) dari 6,57 (44\%) menjadi 11,33 (76\%).

3. Peningkatan partisipasi mahasiswa pada dari siklus I dengan skor rata-rata aktivitas 42,61 meningkat pada siklus II menjadi 75,03

4. Dari data-data yang telah diproleh dapat ditarik kesimpulan bahwa model pembelajaran inquiry terbimbing berbasis JiTT dapat meningkatakan Kemampuan pemecahan masalah mahasiswa
Baser, M. (2006). Effect of Conceptual Change Oriented Instruction on Students, Understanding of Heat and Temperature Concepts, Journal Maltese Education Research. Vol : 4 No. 1 2006. 64-79. Tersedia : www.educ.um.edu.mt/jmer

Bound, J \& Ton, P. (2005). Handbook Problem Solving Laboratory Guide For Students . London : Departement of Materials Queen Mary University of London

Brad, A. (2011). A Study of The Problem Solving Activity in High School Student : Strategies and Self-Regulated Learning. Acta Didactica Napocensia. (Online). 4 (1): 21-30

Erceg, N., Masusic, M. \& Slisko, J. (2011). Students' Strategy for Solving Partially Specified Physics Problem. Revista Mexicana De Fisica. (Online), 57 (1): 4450

Eric. (2003). Teaching Problem Solving Secondary School Science. Tersedia : http://www.ericfacility net/ericdigest/ed 309049 html [20 Nopember 2013]

Gavrin, A. (2006). Just In Time Teaching. Published In Metropolis Universities, 17 (4) : 9-18

Gavrin, A. Watt, J., Marrs, K., \& Blake, R. (2004). Just In Time Teaching: Using The Web to Enhance Classroom Learning. Computers in Education Journal, XVI (2) : 51-59

Gaigher, E., Rogan J. M and Braun, M. W. H. (2007). Exploring The Development of Conceptual Understanding through Structured Problem-Solving in Physics. International Journal of Science Education. 29, (9), 1089-1110

Hamzah, B., Uno, (2008), Model Pembelajaran Menciptakan Proses Belajar Mengajar yang Aktif dan Kreatif, Jakarta : Bumi Aksara.

Indrawati, (2000), Keterampilan Proses Sains, Bandung : Depdikbud-Dirjen Dikdasmen PPPG IPA.

Pical, J. Purniassa, (2004), Penggunaan Langkah Pemecahan Masalah dalam Menyelesaikan Soal Cerita Matematika, Jurnal Pendidikan. Volume I No.2.

Jonassen. (2004). Learning to Solve Problems, An Instructional Desaign Guide. San Fransisco : John Wiley \& Sons, Inc

Jatmiko, Budi (2003) Penelitian Tindakan Kelas. Jakarta: Depdikbud

Joyce, et al, (2011). Models of Teaching. Edisi 8. Yogyakarta: Pustaka Pelajar

\section{DAFTAR PUSTAKA}


Matlin, M. E. (2009). Cognitive Psychology. Seventh Edition. International Student Version. John Wiley \& Sons, Inc.

Mulyasa. (2003). Kurikulum Berbasis Kompetensi, Konsep, Karakteristik dan Implementasi. Bandung : Remaja Rosdakarya.

Olio, D, J., Donk, T. (2007). Models of Teaching, Connecting Student Learning with Standards. California : Sage Publication

Ornek, F., Robinson, W. R. dan Haugan, M. P. (2008). What Make Physics Difficult? . International Journal of Environmental \& Science Education. 3 (1) : 30-34

Petrina, S. (2007), Advanced Teaching Methods for The Technology Classroom, Canada : Information Science Publishing

Reddish, F, E. (2002), Teaching Physics with The Physics Suite, Tersedia : www2.physics.umd.edu/ redish/Book/. [27 Juli 2013]

Saleh, S. (2011). The Level of B.Sc.Ed Students' Conceptual Understanding of Newtonian Physics. International Journal of Academic Research in Business and Social Sciences October 2011, Vol. 1, No. 3 ISSN : 2222-6990

Selcuk, S, G., Caliskan, S., Erol, M. (2008). The Effects of Problem Solving Instruction on Physics Achievement, Problem Solving Performance and Strategy Use. Lat. Am. J. Phys. Educ, 2 (3) : 151-166. Tersedia : http://www.journal.lapen.org.mx Nopember 2013]

Simkins, S., Maier, M. (2010), Just In Time Teaching: New Pedagogis and Practise for Teaching in Higher Education, Virginia : Stylus Publishing, LLC

Sudarma, Teguh febri,. (2013),Efek Model Pembelajaran Kooperatif Tipe STAD berbasis Just it Time Teaching Terhadap Hasil Belajar Fisika Pada Mata Kuliah Fisika Sekolah di Jurusan Fisika FMIPA Unimed. Jurnal Onliene Pendidikan Fisika Vol.2 Juni 2013

Sudarma, Teguh Febri,. (2015), Pengaruh Metode Just-In Time Teaching Terhadap Hasil Belajar Fisika.Jurnal Ikatan Alumni Fisika Universitas Negeri Medan Vol.1 No. 1 Tahun 2015. Tersedia: http://jurnal.unimed.ac.id/2012/index.ph p/jiaf/article/view/38-43

Walsh, L. N., Howard, R. G. \& Bowe, B. (2007). Phenomenography Study of Students' Problem Solving Approach in Physics. Physics Education Research. (Online). 3 (2)
Wijayanti, P.I., Mosik \& Hindarto, N. (2010). Eksplorasi Kesulitan Belajar Siswa Pada Pokok Bahasan Cahaya dan Upaya Peningkatan Hasil Belajar Melalui Pembelajaran Inkuiri Terbimbing. Jurnal Pendidikan Fisika Indonesia. 6: 1-5 